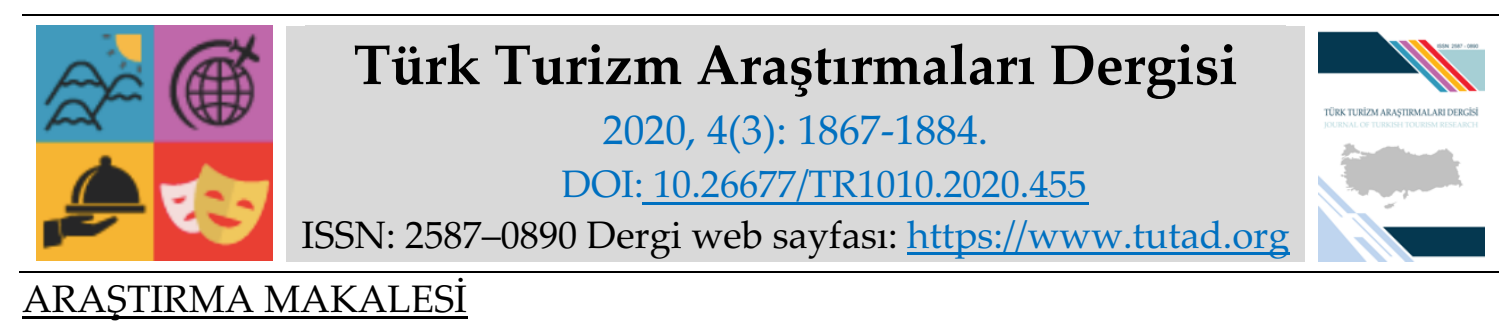

\title{
Destinasyon Pazarlaması Kapsamında Gastronomi Bilgi İçeriklerinin Analizi: Web Siteleri Üzerine Bir İnceleme
}

Dr. Ömür ALYAKUT, Kocaeli Üniversitesi, Kartepe Turizm MYO, Kocaeli, e-posta: omalyakut@gmail.com

ORCID: https://orcid.org/0000-0002-5517-1881

\section{Öz}

Bu çalışmada Kocaeli destinasyon yönetimi paydaşlarının web sitelerinde yer alan gastronomi bilgi içeriklerini ortaya çıkarmak, destinasyon pazarlaması ve rekabetçiliği açısından kullanımlarını değerlendirmek amaçlanmıştır. Gastronomi bilgi içeriklerine ulaşılabilirlik ve bilgi içeriklerindeki uyumu ortaya koymak da çalışmanın diğer amacını oluşturmuştur. Nitel araştırma kapsamında doküman incelemesi yapılan çalışmada, incelenecek dokümanlar amaçsal örneklem yönetimiyle seçilmiştir. Bu kapsamda Kocaeli destinasyon yönetimi paydaşlarından olan merkezi yönetimlerden Kocaeli Valiliği, İl Kültür ve Turizm Müdürlüğü ile yerel yönetimlerden il ve ilçe belediyelerinin web siteleri çalışma kapsamına alınmıştır. Seçilen paydaşların resmi web sitelerine 01.12.2019- 31.12.2019 tarihleri arasında erişim sağlanmıştır. Toplam dokuz web sitesinden elde edilen verilere betimsel analiz uygulanmış ve sonuçlar yorumlanmıştır. Çalışma sonucunda web sitelerinde gastronomi bilgi içerikleri; Kocaeli mutfağ ve özellikleri, yöresel yemekler ve görselleri, tarım ürünleri ve görselleri, gastronomi festivalleri, restoranlar, kültürel kimlikler ve yiyecek çeşitliliği başlıklarında öne çıkmıştır. Ancak Kocaeli'nin zengin gastronomi potansiyeline rağmen paydaşların destinasyon pazarlama aracı olarak gastronomi ürünlerinin çekiciliğinden yeterli düzeyde yararlanmadığı, destinasyon rekabetini gastronomi üzerine kurmadığı ve paydaşlar arasında koordinasyon eksikliği olduğu sonucuna ulaşılmıştır.

Anahtar Kelimeler: Destinasyon Pazarlaması, Destinasyon Yönetimi Paydaşları, Web Siteleri, Gastronomi, Kocaeli.

Makale Gönderme Tarihi: 30.02 .2020

Makale Kabul Tarihi: 02.07.2020

\section{Önerilen Atıf:}

Alyakut, Ö. (2020). Destinasyon Pazarlaması Kapsamında Gastronomi Bilgi İçeriklerinin Analizi: Web Siteleri Üzerine Bir İnceleme, Türk Turizm Araştırmaları Dergisi, 4(3): 1867-1884.

(c) 2020 Türk Turizm Araştırmaları Dergisi. 


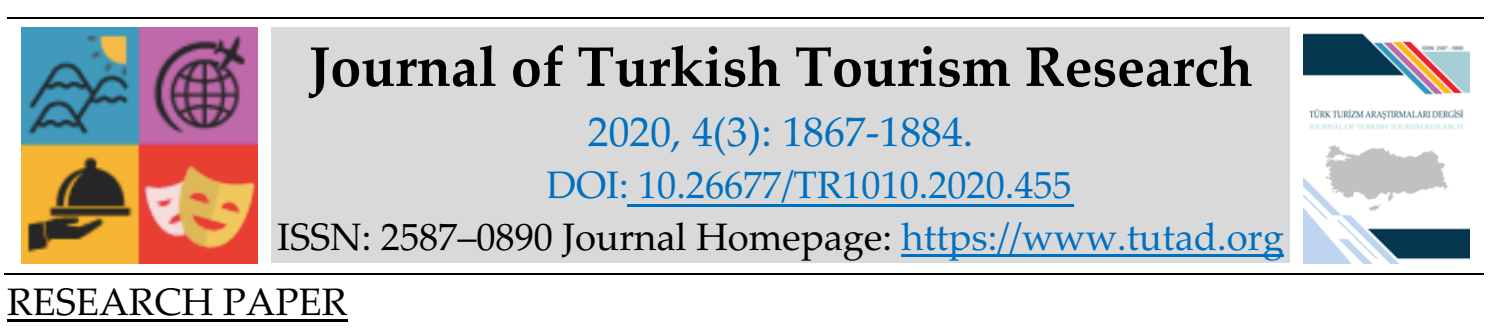

\title{
Analysis of Gastronomy Information Content in Scope of Destination Marketing: A Review on Websites
}

Dr. Ömür ALYAKUT, Kocaeli University, Kartepe Tourism Vocational School, Kocaeli, e-mail: omalyakut@gmail.com

ORCID: https://orcid.org/0000-0002-5517-1881

\begin{abstract}
In this study, it was aimed to reveal the gastronomy information content of the websites of Kocaeli destination management stakeholders and evaluate their use in terms of destination marketing and competitiveness. The other purpose of the study was to reveal the accessibility and harmony of gastronomy information contents. In the study, where document review was conducted within the scope of qualitative research, the documents to be analyzed were selected by the purposeful sampling method. In this context, the websites of Kocaeli Governorship, Provincial Directorate of Culture and Tourism, which are the stakeholders of Kocaeli destination management, and provincial and district municipalities from local administrations were included in the study. Official websites of selected stakeholders were accessed between 01.12.2019 31.12.2019. Descriptive analysis was applied to the data obtained from nine websites and the results were interpreted. As a result of the study, information on gastronomy on the websites came to the fore as Kocaeli cuisine and its features, local dishes and visuals, agricultural products and visuals, gastronomic festivals, restaurants, cultural identities and food diversity. However, despite Kocaeli's rich gastronomic potential, it was concluded that stakeholders did not benefit sufficiently from the attractiveness of gastronomy products as a destination marketing tool, did not establish destination competition on gastronomy and there was a lack of coordination among stakeholders.
\end{abstract}

Keywords: Destination Marketing, Destination Management Stakeholders, Websites, Gastronomy, Kocaeli.

Received: 30.02 .2020

Accepted: 02.07.2020

\section{Suggested Citation:}

Alyakut, Ö. (2020). Analysis of Gastronomy Information Content in Scope of Destination Marketing: A Review on Websites, Journal of Turkish Tourism Research, 4(3): 1867-1884.

(C) 2020 Türk Turizm Araştırmaları Dergisi. 


\section{GİRIŞ}

Turizm destinasyonlarında kültürel değerler, doğal güzellikler, ulaşım, konaklama ve yerel gastronomi ürünleri destinasyonların önemini ve çekiciliğini artırmaktadır (Zağralı ve Akbaba, 2015: 6634). Günümüzde değişen turist davranışlarının özellikle yerel gastronomi ürünlerine olan ilgiyi arttırdı $\breve{g}$, buna bağ lı olarak yerel yemeklerin destinasyon seçiminde önemli rol oynadığ belirtilmektedir (Şahin Güzel ve Ünver, 2015; Aydoğdu vd., 2016; Şengül ve Türkay, 2016; Aydoğdu ve Duman, 2017, Şen ve Aktaş, 2017). Bu noktada son yıllarda kültürel açıdan zengin kentlerin gelişerek turizm cazibe merkezi haline dönüşmesi destinasyon pazarlamasını ve rekabetini de önemli hale getirmiştir. Bu gelişmeye ayak uyduran şehirler ve bu şehirlerin yönetimleri sahip oldukları çekicilik unsurlarını doğru kullanarak fark yaratmaya çalışmaktadır (Çiçek ve Pala, 2017: 26). Bu kentlerden biri Kocaeli ilidir.

Kocaeli; tarihi, doğal çekicilik unsurları, çeşitli turizm çeşitlerine imkan sunan alanları, yerel gastronomi ürünleri ile turizm kenti olma yönünde ilerleyen önemli bir şehirdir. Kocaeli'nin kültürel yapısının çeşitliliği gastronomisini de etkilemiş Yarımca kirazı, Değirmendere fındığı, Kandıra yoğurdu, İzmit pişmaniyesi gibi ürünler öne çıkmış ve bu yörenin adıyla özdeşleşmiştir. Kocaeli'nde coğrafi işaret almış iki gastronomi ürünü vardır. Bunlar; İzmit Pişmaniyesi ve İzmit Simiti'dir. Bu ürünlerin haricinde Kandıra Yoğurdu, Eşme Ayvası, Yarımca Kirazı ile ilgili başvuru yapılmıştır, başvurusu yapılacak ürünlere (Ayva Çezeryesi, Karamürsel Simit Dolması) yönelik hazırlıklar da yürütülmektedir (Yeşilyurt, 2020). Kocaeli' de 2017-2018 sezonunda; 4.095 kişi kapasiteli Turizm İşletme Belgeli toplam 11 yiyecek-içecek işletmesi, tüm ilçelerinde faaliyet gösteren Belediye Belgeli 1060 yiyecek-içecek işletmesi (Kartepe 131, Gölcük 187, Başiskele 92, Kandıra 187, Körfez 43, İzmit 125, Gebze 173, Çayırova 11, Karamürsel 14 ve Darıca 97 tesisi) bulunmaktadır (Kocaeli İl Kültür ve Turizm Müdürlügü̈, 2018). Kocaeli ilini 2019 yılında yaklaşık 660.000 yerli, 110.000 yabancı turist ziyaret etmiştir (Yamen, 2019). Bu anlamda Kocaeli'nin gastronomi değerlerinin ortaya koyulması ve turistik çekicilik unsuru olarak tanıtılması bölgesel rekabet açısından önem arz etmektedir.

Turizm ürünleri kapsaminda gastronomi ürünlerinin de bir bütün halinde planlanması ve yönetilmesi, hedef kitlenin destinasyona çekiminde önemli rol oynamaktadır (Güçer vd., 2013:49). Destinasyon yönetiminde yer alan merkezi ve yerel yönetimlerin kendi destinasyonlarını tanitma ve pazarlama faaliyetleri kapsamında resmi web sitelerini etkili kullanmaları gerekmektedir. Çünkü günümüzde turistlerin büyük çoğunluğu seyahat planlarını yapmaya, destinasyonlarla ilgili web sitelerini inceleyerek başlamaktadır. Bu konuda yapılan çalışmalarda turistlerin kentin turistik cazibe unsurlarına veya destinasyonun öne çıkan değerlerine merkezi ve yerel yönetimlerin web sitelerinden erişir oldukları ve bu sitelerin karar verme süreçlerini etkilediği belirtilmektedir (Eryllmaz ve Zengin, 2011; Zhou ve Desantis, 2005 akt. Güçer vd., 2013; Yazıcı ve Ekinci, 2017; Güllü, 2018).

Buradan hareketle çalışmada Kocaeli destinasyon yönetimi paydaşları arasından amaçsal örneklem yönetimiyle seçilen merkezi yönetimlerden Kocaeli Valiliği, İl Kültür ve Turizm Müdürlüğü ile yerel yönetimlerden il ve ilçe belediyelerin web sitelerinde, yerel gastronomi ürünlerine yönelik bilgilendirmelerin varlığı ve içeriği incelenmiştir. Bu kapsamda turizm kenti olma yolunda ilerleyen Kocaeli'nde seçilen destinasyon yönetimi paydaşlarının hangi gastronomi unsurlarını öne çıkardığı ve bu unsurların destinasyon pazarlaması ve rekabetinde kullanımları değerlendirilmiştir. İlaveten paydaşların bilgi içeriklerine ulaşılabilirlik ve bilgi içeriklerindeki uyum da ortaya koyulmaya çalışılmıştır. Nitel araştırma yönteminin uygulandığı çalışmada doküman incelemesi yapılmış, elde edilen verilere betimsel analiz uygulanmıştır. 


\section{TEORIK ALTYAPI}

Teorik altyapı başlı̆̆ı altında öncelikle destinasyon kavramı ve gastronomi ürünlerinin turizm destinasyonunda yeri ve önemi açıklanmıştır. Ardından destinasyon pazarlamasında tanıtım aracı olan web siteleri kısaca ele alınmıştır.

\section{Destinasyon Kavramı ve Gastronomi Ürünlerinin Turizm Destinasyonundaki Yeri ve Önemi}

Sözlük anlamıla destinasyon, varılacak olan yer (TDK, 2019), turizm destinasyonu ise; turist toplumunun yerel toplum içinde bulunduğu coğrafi bir yer ya da bölge olarak tanımlanmaktadır. Destinasyonlar tüketicilere iç içe geçmiş tecrübeler bütünü sunan turizm ürünlerinin bileşiminden oluşmaktadır (Özdemir, 2014: 5). Destinasyon ürünü, alışveriş yapmak, yemek, ulaşım, konaklama vb. unsurlardan oluşan hizmet altyapısı ile doğal çevre, politik, yasal, ekonomik, kültürel teknolojik faktörlerden oluşan destinasyon çevresinin bileşkesinin ortaya çıkardığı destinasyon deneyimi olarak tanımlanmaktadır. Bu nedenle bir destinasyonun benzersizliğinin nedeni, destinasyonun karmaşık yapısını oluşturan bileşenlerin kendilerine özgü özellik ve yapılarından gelmektedir (Özdemir, 2007: 2). Turizm bölgeleri, turizm hareketlerinin odak noktalarından birisi konumundadır. Bireylerin geçici yer değiştirmelerinin esas amacı, genellikle belirli bir turizm bölgesini ziyaret etmektir. Bu bölgeler, çeşitli cazibe unsurları nedeniyle ziyaretçileri kendilerine çekmektedir (Sarı ve Kozak, 2005: 248). Çekicilik unsurları ziyaretçilerin eğlenmesi, keyif alması ve eğitilmesi amacıyla yönetilen ve kontrol edilen kaynaklardan (tarih, kültür, sanat, spor etkinlikleri, eğlence ve alışveriş) oluşmaktadır (Karabıyık ve İnci Sümer, 2012: 2). Turizm dünyanın en büyük endüstrilerinden biri ve bir hizmet sektörü olarak hem somut hem de soyut kaynakları temel almaktadır. Destinasyon bu karmaşık yapıyı temsil eden bir sistem olarak nitelendirildiği için bir destinasyonu oluşturan işletmelerin, devlet kurumlarının, belediyelerin ve yerel halkın ortak bir amaç doğrultusunda birlikte hareket etmeleri gerekmektedir (Özdemir, 2014: 6).

Destinasyon yönetimi olgusuyla ortak bir yönetim anlayışı ortaya çımakta ve benimsenmektedir. Destinasyon yönetimi, öz-kaynaklar ve çekiciliklerin etki gücünü artıracak, destekleyici faktörlerin kalitesini ve gücünü geliştirecek ve niteliksel belirleyenlerin ortaya çıkardığı çerçeveye en iyi uyumu ortaya koyacak tüm uygulamaları kapsamaktadır (Türkay, 2014:169-170). Destinasyon yönetiminde yer alan paydaşlar, destinasyon yönetim örgütünü oluşturmaktadır. Destinasyon Yönetim örgütü (DMO); bir coğrafi bölge, alan ya da şehri, bir turistik destinasyon olarak ele alan ve bu yönde çalışmalar yürüten örgüttür. Destinasyon yönetim örgütü; turizm gelirlerini artırmak, istihdam yaratmak, turizmi bölgesel ve mevsimsel olarak yaymak, turistlerin ilgisini sürdürmek, gelişim sağlamak gibi ortak amaçlara sahiptir. Turizmin toplam 32 paydaşı olmakla birlikte destinasyon yönetim örgütü yöneticileri tarafından en önemlileri; oteller, devlet kurumları (farklı düzeylerde), çekim merkezleri, restoranlar, üniversiteler, yerel ticaret odaları, yerel halk vb. olarak sıralanmaktadır (Özdemir, 2014: 66). Paydaşların gücü kendilerine ait kapasitenin (üretim, insan kaynağı, sermaye vb.) yönetim sürecinde karşılaştığı fırsatlar ve yönetime katılma isteğinden gelmektedir.

Destinasyon yönetim paydaşlarından olan ve çalışmanın örneklemini oluşturan Kocaeli Valiliği, İl Kültür ve Turizm Müdürlüğü, Büyükşehir ve ilçe belediyelerinin kent turizminin gelişiminde ve tanıtılmasında önemli görevleri vardır. Destinasyon yönetim örgütünün en önemli paydaşlarından olan yerel yönetimler, merkezi yönetimden aldıkları yetki ve görevler çerçevesinde turizm faaliyetlerinde bir aktör konumundadır ve bölgesel turizm üzerinde önemli bir rol üstlenmektedirler. Bu kapsamda belediyeler; alt yapı- üst yapı çalışmaları, turizmin ihtiyaç 
duyduğu tesisleşmenin gelişimi ve turizm tesislerine arazi tahsis etme gibi karar almada hukuki sorumluluklara sahiptir (Türkay, 2014: 24). Turist, bir bölgeye gittiği andan itibaren, belediyelerin yapmış oldukları hizmetlerle karşı karşıya kalmaktadır (Güllü, 2018: 39). Kültür ve Turizm Bakanlığı ve il müdürlükleri de, ülke veya bulunduğu il genelinde turizmin geliştirilmesi ve yönetilmesi konumunda etkin bir kurum olarak görevlendirilmiştir. Bu kapsamda milli, manevi, tarihi, kültürel ve turistik değerleri araştırmak, geliştirmek, korumak, yaşatmak, değerlendirmek, yaymak, tanıtmak, pazarlamak, benimsetmek bu sayede ülke ekonomisine ve milli bütünlüğün güçlenmesine katkıda bulunmak gibi sorumlulukları bulunmaktadır. Ayrıca bölgeye uygun turizm politikaları, yatırımları oluşturmak ve yönlendirmek, önem taşıyan değerlerin envanterini oluşturmak da sorumlulukları arasında sayılabilir (Türkay, 2014: 24-32) İl merkezi yönetimleri ise (Kocaeli Valilik), turizm ve kültür konusunda bütün programlama, örgütleme, organize etme ve denetleme işlevlerini yerine getirmekle yükümlüdür. Bu bilgiler doğrultusunda yerel yönetimlerin turizm ve kültür alanında yaptığı etkinlikler birbirini destekler ve tamamlar nitelikte olması gerekmektedir. Olalı (1990 akt. Genç vd., 2014: 50) bu durumu ahenkli çalışma olarak ifade etmekte ve turizmle uzak veya yakın ilişkisi olan bütün kuruluşların, kişilerin arasında koordinasyonun olması gerektiğini belirtmektedir. Çünkü ziyaretçi bir destinasyonu ziyareti sırasında tek bir unsurdan faydalanmaz, birleşik bir ürünle ilgilenir. Destinasyona gelen ziyaretçi otelde konaklama yapar, restoranda yemek yer, ulaşım araçlarını kullanır, alışveriş yapar, eğlence mekânlarına gider. $\mathrm{Bu}$ nedenle gelen ziyaretçilerin memnuniyetinin sağlanmasında tüm paydaşlara önemli sorumluluklar düşmektedir.

Turist çekme yarışındaki her destinasyon bir diğerinin rakibidir. Bu nedenle bir destinasyon için destinasyonun varlıkları ve pazarın dinamiklerine bağlı bir rekabet gücü tanımlaması yapılabilir. Destinasyon rekabetçiliği, bir destinasyonun rakiplerine karşı pazar payını koruyan kaynakların devamlılığını sağlayacak şekilde katma değerli ürünler oluşturma kabiliyetidir. Destinasyonların rekabet gücünü; destinasyonun rakiplerinden farklı olarak sahip olduğu göreli üstünlükleri ve üstünlüklerin kullanılabilmiş olmasına bağlı olarak ortaya çıan rekabetçi üstünlük oluşturmaktadır (Türkay, 2014: 157-159).

Destinasyonların çekicilik unsurlarından en önemlisi sahip olduğu tarihi varlıkları ve kültürel mirasıdır (İpar, 2011: 42). Bugün turistik ürün çeşitlendirmesi için gastronomi, kültürel miras olarak destinasyon ziyaretinin bir parçası ve turistlerin yeni ve özgün deneyimleri ile en önemli seyahat motivasyonlarından biridir. Bu bağlamda gastronomi turizmi, yerel mutfak ürünleri ile kültürlerin birbirlerini daha iyi tanımalarını sağlamakta, bir destinasyonun turistik kaynaklarının daha aktif ve keyifli hizmet sunması, turistlerin tatmini, yerel halkın üretimi, refahı ve sürdürülebilirlik açısından kalkınmalarına da destek olmaktadır (Rand ve Heat, 2006; Lopez ve Martin, 2006: akt.; Göker, 2011). Gastronomi ürünleri birçok ülke ve bölge için yeni bir turizm pazarını temsil etmekte ve turistik destinasyonlar ile bu destinasyonlardaki girişimciler için benzersiz bir rekabet avantajı sağlamaktadır. İlaveten destinasyonların pazarlanmasında önemli bir pazarlama aracı olarak yılın on iki ayı gerçekleştirilebilmektedir. Böylece o destinasyon; turizmin sağladığı ekonomik, sosyo-kültürel, alt yapı vb. avantajlardan on iki ay boyunca fayda sağlayabilmektedir (Alyakut, 2017).

Gastronomi ve gastronomi kültürü, turist için destinasyon tercihinde en çok ilgi duyduğu çekicilik unsurlarının başında gelmektedir. Çünkü her misafir gittiği ülkenin mutfağını, lezzetlerini merak etmekte ve deneyimlemek istemektedir (Aydoğdu vd., 2016:126; Şahin Güzel ve Ünver, 2016:66; Gülen, 2017:39). Yapılan çalışmalarda yerel gastronomi ürünlerinin bir destinasyonda ayırt edici özellik olarak sürdürülebilir rekabet üstünlüğü sağladığ 1 ve destinasyon pazarlamasında kullanıldığı belirtilmektedir (Erdoğan vd. 2011: 12; Çevik ve Saçılık, 2011: 513; Çalışkan, 2013: 41; Serçek ve Serçek, 2015; Draskovic, 2016: 153; Rinaldi, 2017: 15; Deniz ve Atışman, 2017: 65). 
Türkiye Seyahat Acentaları Birliği'nin (TÜRSAB-2014) Gastronomi Turizmi Raporunda; günümüzde 1 milyardan fazla turist olduğu ve bu turistlerin $\% 88,2$ 'sinin destinasyon tercihlerinde yerel gastronomi ürünlerinin çok önemli olduğunu ifade ettikleri belirtilmiştir. Gastronomi Turizmi Derneği ve Xsights Araştırma Şirketi'nin Gastronomi Turistlerine Yönelik Araştırma (2017) sonuçlarında ise gastronomi turistlerinin normal turistlere göre $\% 50$ daha fazla para harcadığı, Türkiye'de ortalama 7 gün kaldıkları, ortalama 945 doların 259 dolarını yeme içmeye harcadıkları ortaya koyulmuştur (Toprakkaya, 2017).

Bugün destinasyonlar gastronomi turizminin diğer turizm türleriyle kolaylıkla entegre olması ve turizmin çeşitlendirilerek turistik çekiciliği artırması sebebiyle gastronomi turizmini bir tanıtım ve pazarlama aracı olarak kullanmaktadır (Marangoz ve Karadağ, 2017; Bulut, 2019). Bu kapsamda destinasyon yönetim paydaşları olan belediyeler, valilik ile il kültür ve turizm müdürlükleri çeşitli etkinlikler düzenlemekte ve bunları web sitelerinden duyurarak tanıtım ve pazarlama çalışmalarını sürdürmektedir. Özellikle kurumlar web sitelerinden ya da sosyal medya hesaplarından; festivalleri, doğa sporlarını, gastronomi etkinliklerini (yemek yarışmaları, gastronomi kursları, etnik mutfaklar vb.) duyurarak, diğer turistik destinasyonlar ile rekabette bir adım öne çıkmaya çalı̧̧maktadır. Konuya ulusal düzeyde yapılan çeşitli çalışmalarla da dikkat çekilmiştir (Yılmaz ve Özdemir, 2015; Uluçay, 2017; Yazıcı ve Ekinci, 2017; Güllü, 2018; Akkuş ve Akkuş, 2019). Bu çalışmanın da konusunu oluşturan yerel gastronomi unsurları turizm destinasyonlarının sürdürülebilirliği ve tanıtımında en önemli enstrüman olarak karşımıza çıkmaktadır. Dolayısıyla günümüzde turizm sektörünün ülke ekonomisine katkıları değerlendirildiğinde, turizm ürünlerinin yanı sıra gastronomi ürünleri ve gastronomi turizmine yönelik artan rekabet dikkat çekmekte ve gastronomi ürünleri rekabet ortamı doğurmaktadır (Çakır ve Küçükkambak, 2016: 403). Bu nedenle merkezi ve yerel yönetimlerin web sitelerinde destinasyon tanıtımı ve pazarlaması için yerel gastronomiye ait bilgilendirmenin yapılması önem arz etmektedir.

\section{Destinasyon Tanıtım ve Pazarlama Aracı Olarak Web Siteleri}

Turizm ve tanıtım kavramları birbiriyle yakından ilişkili olan iki kavramdır. Bir ülkenin turizm sektöründe söz sahibi olabilmesi tanıtımının doğru yapılmasına bağlıdır. Tanıtımı iyi yapılamayan hiçbir şeyin değeri yoktur. Turizm sektöründe her kurum ve kuruluşun belirli hedefleri vardır. Kurumlar hedeflerini gerçekleştirmek için ülkenin turizm değeri taşıyan varlıklarını tanıtmayı amaçlamaktadır (Duğan ve Aydın, 2018: 3). Tanıtma, bir ülke veya birim hakkında, onun menfaatlerine uygun, onun lehinde olumlu imaj yaratmak, saygınlığını artırmak amacıyla belirli bir plan ve politika dahilinde, bir koordinasyon içinde, açık, sürekli, yoğun ve sistemli bir şekilde yürütülen faaliyetler olarak isimlendirilmektedir. Tanıtımın etkili olabilmesi için sürekli olması, aynı amaca hizmet etmesi ve bir koordinasyon çerçevesinde hareket edilmesi gerekmektedir. (Hacıŏglu, 2010: 71).

Pazarlama ise, tüketicileri tatmin etmek ve işletme amaçlarına ulaşmak için mal ve hizmetlerin üreticiden tüketiciye veya kullanıcıya doğru akışını yönelten işletme faaliyetlerinin yerine getirilmesi olarak tanımlanmaktadır (Hacıŏglu, 2010: 1). Bir turizm destinasyonun çekiciliğini artırabilmek hedef destinasyonun iyi bir şekilde yönetilmesi ve destinasyonun pazarlanması ile mümkündür (Doğaner ve Armağan, 2017: 226).

Destinasyon pazarlaması bölge insanının uzun bir süreçte refahını sağlamakta, turistleri memnun etmekte, yerel halkın kalkınmasına katkı sağlamakta ve sosyal-kültürel-çevresel ve ekonomik sürdürülebilirliği sağlayarak turizmin etkilerini arttırmaktadır (Karabıyık ve İnci Sümer, 2012: 2). Pazarlama genellikle tutundurma faaliyetleri ile ilgili görülmektedir. Hedef pazarın belirlenmesi, ürün geliştirme, uygun fiyatlama ve verimli dağıtım kanalları 
kombinasyonun belirlenmesi gibi çok önemli etkinlikler destinasyon pazarlama uygulamaları arasında yer almaktadır (Türkay, 2014: 169-170).

Turizmde destinasyon tanıtımı ve pazarlamasında tüketicilerin tutumları yoğun bilgi ile şekillenmektedir. (Doğaner ve Armağan, 2017: 226). Günümüz bilgi toplumunda bilgiye ulaşmanın en kısa yolu internettir. İnternet vasıtasıyla kurum ve/veya kuruluşlar, yeni tanıtım ve pazarlama olanaklarına sahip olmaktadır. İnternet kaynak ile alıcı arasında çift yönlü işleyen etkileşimli/interaktif bir iletişim ortamı sunmaktadır (Elden, 2003: 254). İnternet tabanlı Web (www) ya da W3 (World Wide Web), "global ağ terimi", dünyanın her yerindeki binlerce web sunucuları adı verilen bilgisayarlarda kayıtlı milyonlarca dosyadan oluşan bir bütündür. Yazı, resim, ses, film, animasyon gibi pek çok farklı yapıdaki verilere kompakt ve etkileşimli bir şekilde ulaşılmasını sağlayan çoklu hiper ortam sistemidir. Dosyaları bir arada tutan, bir dosyayı diğerine aktaran ve onları internet üzerinden yollayan bir bağlantı sistemi (Sayımer, 2012: 27) olan web, geniş kitlelere daha düşük maliyetle ulaşmayı sağlamakta, kullanıcılara enformasyon aktarmakta, reklam ve pazarlama imkanı yaratmakta, iletişime ve geribildirime olanak sağlamaktadır (Koç, 2015: 60). Bir iletişim aracı ve dağıtım kanalı olarak web siteleri, turistlerin destinasyon hizmetleri hakkında kolayca bilgi sahibi olmalarına ve bu hizmetleri kendileri bir araya getirerek seyahatlerini istekleri ve bütçeleri doğrultusunda planlamalarına yardımcı olmaktadır (Özdemir, 2007; Çiçek vd., 2013; Güçer vd., 2013). Ayrıca turistlerin karar verme süreçlerine de katkı verebilmek için kapsamlı, zamanlı ve gerekli bilgiyi rahatlıkla elde edebilmelerini sağlamakta ve destinasyon imajı oluşturmaya destek olmaktadır. İlaveten turistlerin tüketim alışkanlıklarına, yaşam tarzlarına ve davranış biçimlerine etki etmekte ve o destinasyona güdülemektedir (Eryılmaz ve Zengin, 2011).

Turistleri destinasyona güdüleyen turistik çekiciliklerden biri de yerel gastronomi ürünleridir. Bir destinasyon için yerelliği sürdüren ve ait olduğu destinasyonun kültürünün bir göstergesi olan lezzetleri yani yöreselliği son derece önemlidir. Bu nedenle birçok ülke ve bölge, destinasyon yönetimi paydaşlarından olan devlet destekli web sitelerinde turistlerin destinasyona yönelik aradığı bilgiler arasına yerel gastronomi ürünlerine ait bilgileri de koymaktadır (Benli ve Güler, 2019: 828). Böylece web siteleri aracılığıyla turistlere güvenilir bilgi iletilmekte, destinasyonun tanıtılmasına ve tercih edilmesine katkı sağlanmaktadır.

\section{ARAŞTIRMA YÖNTEMI}

Çalışmada Kocaeli destinasyon yönetimi paydaşlarından olan merkezi ve yerel yönetimlerin web sitelerinde yerel gastronomi ürünlerine yönelik bilgilendirmelerin varllğı ve içeriği incelenmiş ve gastronomi ürünlerinin kullanımı destinasyon pazarlaması ve rekabetçiliği kapsamında değerlendirilmiştir. İlaveten bu paydaşların gastronomi bilgi içeriklerine ulaşılabilirlik ve içeriklerindeki uyum da ele alınmıştır. Bu çalışmanın planlanmasında Yılmaz ve Özdemir'in (2015) çalışması yol gösterici olmuştur. Çalışmanın evrenini Kocaeli destinasyon yönetimi paydaşlarının web siteleri oluşturmuştur. Örneklemini ise amaçsal örneklem yöntemiyle seçilen Kocaeli destinasyon yönetimi paydaşları olan merkezi yönetimlerden Kocaeli Valiliği, Kocaeli İl Kültür ve Turizm Müdürlügü ile yerel yönetimlerden Kocaeli Büyükşehir Belediyesi ve ilçe belediyelerin (Başiskele- Gebze- Dilovası- Gölcük- İzmit- Kartepe- Çayırova- Derince- DarıcaKandıra- Karamürsel- Körfez) web siteleri oluşturmuştur. Nitel araştırma kapsamında ele alınan bu çalışmada verilerin elde edilmesinde doküman taramasından yararlanılmıştır. Tarama modelleri geçmişte ya da halen var olan bir durumu var olduğu şekliyle betimlemeyi amaçlayan araştırma yaklaşımlarıdır. Bu modelde araştırma konusu olan olay, olgu, nesne, birey vb. kendi koşulları içinde ve olduğu gibi tanımlanmaya çalışılır (Karasar, 2011: 77). 
Seçilen paydaşların resmi web sitelerine 01.12.2019- 31.12.2019 tarihleri arasında bir ay süreyle erişim sağlanmıştır. Toplam on beş web sitesinden altı web sitesi gastronomi çekiciliklerine yönelik bilgilendirme yapmadığından dokuz web sitesi çalışma kapsamına alınmıştır. Bu kapsamda seçilen paydaşların web sitelerinde aşağıdaki sorulara cevap aranmıştır.

- Web sitelerinde gastronomi bilgi içeriği var mıdır?

- Web sitelerinde yer alan gastronomi bilgi içerikleri nelerdir, öne çıkan başlıklar hangileridir?

- Web sitelerindeki gastronomi bilgi içeriklerine kolay ve hızlı ulaşılmakta mıdır?

- Web sitelerinde yer alan gastronomi bilgi içerikleri arasında uyum var mıdır?

Doküman incelemesi sonucunda elde edilen veriler betimsel analiz yöntemiyle değerlendirilmiştir. Yıldırım ve Şimşek'e (2018) göre betimsel analiz; elde edilen verilerin daha önceden belirlenen temalara göre özetlenmesi ve yorumlanmasıdır. Bu kapsamda elde edilen veriler araştırma sorularının ortaya koyduğu temalara göre düzenlenebilir. Ortaya çıkan temaların ilişkilendirilmesi, anlamlandırılması ve ileriye yönelik tahminlerde bulunulması da, araştırmacının yapacağı yorumların boyutları arasında yer alır. Bu kapsamda çalışmada öncelikle sorular çerçevesinde paydaşların web sitelerinde yer alan gastronomi bilgi içerikleri incelenmiş ardından temalar oluşturularak içerikler açıklanmış ve yorumlanmıştır. Bu kapsamda dört tema oluşturulmuştur. Bu temalar; "Web Sitelerinde Paylaşılan Gastronomi Bilgi İçeriklerinin Varlığı", 'Web Sitelerinde Gastronomi Bilgi İçerikleri", " Web Sitelerinde Gastronomi Bilgi İçeriklerine Ulaşılabilirlik" ve "Web Sitelerinde Paylaşılan Gastronomi Bilgi İçeriklerinde Uyum" olarak belirlenmiştir.

Çalışma; seçilen Kocaeli destinasyon yönetimi paydaşlarına ait dokuz web sitesindeki gastronomi bilgi içerikleri ile sınırlandırılmıştır. Dinamik olan web siteleri her an güncellenebilir olduğundan elde edilen veriler inceleme tarihleri ile sınırlıdır.

Çalışmanın geçerlilik ve güvenirliliğini artırmak için gastronomi ve turizm alanında uzman iki öğretim üyesinin görüşüne başvurulmuş, çalışmanın ayrıntıları ve bulguları aktarılarak görüşleri alınmıştır. Gelen geri bildirimler sonucu düzeltmeler yapılmış ve çalışmaya son şekli verilmiştir. Böylece araştırmanın niteliği artırılarak geçerlik ve güvenirliğe katkı sağlanmıştır (Yıldırım ve Şimşek, 2018).

\section{BULGULAR ve TARTIŞMA}

Seçilen Kocaeli destinasyon yönetimi paydaşlarının resmi web sitelerinde yer alan gastronomi içerikleri oluşturulan temalar altında açıklanmış, destinasyon pazarlaması ve rekabetçiliği kapsamında tartışılarak yorumlanmıştır.

\section{Tema 1: Web Sitelerinde Paylaşılan Gastronomi Bilgi İçeriklerinin Varlığı}

Kocaeli Büyükşehir Belediyesi ile yedi belediyenin yerel gastronomi ürünlerine yönelik bilgilendirme yaptığı görülmüştür. Ancak yerel yönetimlerden Çayırova, Derince, Darıca, Kandıra, Karamürsel ve Körfez belediyeleri web sitelerinde, yerel gastronomi ürünlerine yönelik bilgilendirmeye rastlanmamıştır. Bu kapsamda yerel yönetimlerin yarısının gastronomi unsurlarını çekicilik unsuru olarak kullanmadığı, destinasyon tanıtımı ve pazarlamasını bu yönüyle eksik bıraktığı anlaşılmıştır. Oysa Kocaeli gastronomisine yönelik Alyakut ve Küçükkömürler'in (2019) yaptığı çalışmada, Kocaeli'nin kültürel çeşitliliğinden dolayı yörede yaklaşık 1000 çeşit yemek olduğu, bu yemek zenginliğiyle Kocaeli mutfağının, Yaratıcı Şehirler 
Ağı'na giren Gaziantep ve Hatay mutfağıyla yarışabilecek gastronomi potansiyeline sahip olduğu ortaya koyulmuştur.

Merkezi yönetimleri temsil eden paydaşların web sitelerinde ise bu bilgilere paralel olarak, yerel gastronomi ürünlerine yer verildiği, bu paydaşların destinasyon rekabetini avantaja çevirmeye yönelik yerel gastronomi ürünlerinin çekiciliğinden yararlanmaya çalıştıkları anlaşılmıştır. Destinasyonlar, yerel yemeklerin kültürünü tanıtarak turistin tercihlerini etkileyebilmektedir. Özellikle Gastronomi Turizmi, yiyecek-içecek ve turizm arasındaki bağın kurulmasını sağlayan yerel kimliğin ve kültürün güçlenmesine yardımcı olmaktadır. Bu anlamda Gastronomi Turizminin hayata geçirilmesi ve varlığının korunması, sosyal ve kültürel değerlere sahip çıkarak özendirilmesi, tarihi dokuların korunması ve gelecek nesillere taşınması destinasyonların tanıtımı, rekabeti ve pazarlamasında yardımcı unsur olarak öne çıkmaktadır (Aydoğdu ve Duman, 2017: 18).

\section{Tema 2: Web Sitelerinde Gastronomi Bilgi İçerikleri}

Yerel yönetimlerin gastronomi bilgi içerikleri değerlendirildiğinde; Kocaeli'nin önemli turizm destinasyonlarından biri olan Kartepe'de, yerel belediyenin yörenin zengin mutfağını yeterince yansıtmadığı genellikle yöresel yemeklerden ziyade ticari olarak restoranların menülerinde yer alan yemeklerin öne çıkarıldığı sadece birkaç yerel lezzete yer verildiği dikkat çekmiş̧tir. Bu kapsamda Kartepe belediyesinin yöre mutfağını tanıtmaya ve gastronomi turizmini geliştirmeye yönelik yeterince bilgi içeriği paylaşmadığı ve destinasyon tanıtımı ve rekabetinde var olan potansiyeli tam olarak kullanmadığı görülmüştür. Oysa yapılan çeşitli çalışmalarda Kartepe'nin kültürel çeşitlilik gösteren demografik yapısının yöre gastronomisine yansıdığı ve yöresel yemek çeşitliliğinin zengin olduğu bildirilmiştir (Alyakut ve Küçükkömürler, 2019; Alyakut ve Üzümcü, 2017).

Başiskele Belediyesi'nin web sitesinde yörede yaşayan Manavlarla özdeş olan Dartı'nın öne çıkarıldığı görülmüştür. Dartı yapılışı ve görseline yer verilerek özel bir sos olan bu lezzet hakkında tanıtıcı bilgi verilmiştir. Dartı; çiğ süt kaymağının kaynatılmasıyla elde edilen yöreyle özdeş bir sostur. Yörede kahvaltılarda tüketildiği gibi yemeklerin üzerine ya da içine koyularak da tüketilmektedir (Alyakut ve Üzümcü, 2017). Bu kapsamda destinasyon pazarlamasında ve rekabetinde avantaj sağlayan bir ürün olarak öncelenmesi önemlidir.

Gebze Belediyesi'nin web sitesinde yöresel yemeklerin öne çıarıldığg görülmüştür. Ancak bu yemeklerin reçetelerine, hikâyelerine ve/veya görsellerine yer verilmediği gibi yöresel olan ya da olmayan restoranlara yönelik bilgiye de rastlanmamıştır. Bu kapsamda İstanbul'a yakın olan ve iş turizmi merkezlerinden birini oluşturan Gebze'de temel beslenme ihtiyacını karşılayacak restoranlara (ya da yöresel restoranlara) yer verilmemesi dikkat çekicidir.

Dilovası Belediyesi web sitesinde yörede bulunan zeytincilik ve bu kapsamda açılan yağhaneler konusunda bilgi verildiği ve halkın geçim kaynağı olan meyve ve bağcllık faaliyetleri ile hayvancılık faaliyetlerinin kültür ve turizm kapsamında ele alındığı görülmüştür. Bilgilendirmenin devamında Kocaeli'nin sanayi kenti olmaya başlamasıyla mutfak kültüründeki değişimin kaçınılmaz sonucu yerel gastronomi ürünlerinin üretimi ve tüketiminin değiştiği açılanarak turizm destinasyonu olma yolunda ilerleyen Kocaeli'de gastronomi turizminin nasıl olumsuz etkilendiği/etkileneceği ortaya koyulmuştur. Belediyenin küreselleşmenin olumsuz etkilerinden özellikle gastronomi ürünlerine dikkat çekmesi önemlidir. Çünkü önlem alması gereken kurum ve kuruluşlar olduklarından tarımsal faaliyetler ile gastronomi ürünlerinin sürdürebilirliğine katkı sağlayacakları ümit edilmiştir. 
Gölcük Belediyesi web sitesinde yöreyle özdeş olan Değirmendere fındığı, Sting ve Golden cinsi elma, fasulye ve Avidere içme suyunun öne çıkarıldığı görülmüştür. İlaveten yörede yaşayan çeşitli kültürel kimliklere (Gürcü, Abhaz gibi) ait yemekler sadece isimleriyle anılmış, reçeteleri, görselleri ya da sunulduğu restoranlar gibi ayrıntılara girilmemiştir. Yörede her yıl düzenli olarak yapılan geleneksel Fındık Festivali ile diğer festivaller belirtilmiş ancak detayları verilmemiştir. Özellikle Körfez Belediyesi'nin web sitesinde hiçbir gastronomi ürününe yer vermemesi şaşırtıcıdır. Çünkü ilçeye özgü olan Yarımca Kirazı ve her yıl yapılan geleneksel Altın Kiraz Festivali etkinlik turizmi/ gastronomi turizmi açısından turistik çekicilik unsurlarından biridir. Aynı şekilde Kartepe ilçesinin Eşme mahallesinde yetişen Eşme ayvası ve Eşme Ayva Festivali de Kartepe Belediyesi'nin web sitesinde yer almamıştır. Paydaşların böyle bir tutum sergilemesi destinasyonların sürdürülebilirliğini ve yerel kalkınmayı olumsuz etkilemektedir. Oysa festivaller, bir destinasyonda veya ev sahipliği yapan toplulukta ciddi ölçüde ekonomik, sosyo-kültürel ve politik etkilere sahiptir (Illban ve Kömür, 2019:276). Çünkü festivalleri diğer etkinliklerden farklı kılan, gerçekleştirildiği toplumu yansıtması, o topluma özgü olması ve bir toplumun kendini ifade tarzı olmasıdır (Albayrak, 2013). Bu noktada toplulukların değerlerini, ideolojilerini, kimliğini ve sürdürülebilirliğini de sağlamaktadır (Getz, 2008). Dünyada çok sayıda ülke; yöresel, ulusal ve uluslararası festivalleri ile her yıl on binlerce turisti çekmektedir (İlban ve Kömür, 2019:276). Bu kapsamda Gölcük, Körfez, Kartepe belediyelerinin destinasyon rekabet avantajını yeterince kullanamadığı, destinasyonun ve turizmin sürdürülebilirliğine yeterince katkı sağlayamadığı anlaşılmıştır.

Diğer yandan merkezi yönetimlerin yöreyle özdeş, bilinen ürünler ile bunların reçeteleri, hikâyeleri, görselleri gibi ayrıntıları paylaştığı ancak diğer ürünlere pek yer vermediği ve ayrıntılarını da paylaşmadığı görülmüştür. İl Kültür ve Turizm Müdürlügü̈nnün Kocaeli'nin gastronomi potansiyeline yönelik en geniş ve kapsamlı bilgiyi vererek destinasyonun gastronomi çekiciliğinden yararlandığı ancak tamamıyla potansiyeli ortaya koyamadığı anlaşılmıştır. Çalışmanın giriş bölümünde belirtildiği gibi Kocaeli'de coğrafi işaretli ürünlerin sayısı artmış ve başvuru sürecinde yöreyle özdeş ürünler bulunmasına rağmen bunlarla ilgili güncel bilgilere yer verilmediği görülmüştür. Bu kapsamda destinasyon rekabet avantajının da yeterince kullanılmadığı dikkat çekmiştir.

Merkezi yönetimlerin (Kocaeli Valiliği ve İl Kültür ve Turizm Müdürlüğü) yanı sıra Büyükşehir Belediyesi ve merkez ilçe olan İzmit Belediyesi'nin web sitelerinde; Kocaeli'yle anılan ve coğrafi işaret alan yöresel tatlı Pişmaniye tanıtılmış, turistik ürün haline gelen bu tatlının tarihçesi, reçetesi ve görsellerine yer verilmiştir. Pişmaniyenin uluslararası piyasalarda yerini alması ve korunabilmesi için 13.06.2001 yayın tarihi ile menşe işareti alınmış ve coğrafi işaretli Kocaeli'nin ilk ürünü olmuştur (YUCITA, 2018). Bu anlamda pişmaniyenin turistik ürün olarak web sitesinde yer alması Kocaeli destinasyonuna farkındalık yaratmakta, destinasyonunun diğer destinasyonlarla rekabet edebilmesine olanak sağlamaktadır. Coğrafi işaretli ürünlere web sitelerinde yer verilerek yerel kalkınmaya da destek olunabilir.

Paylaşılan yerel gastronomi ürünleri haricinde diğer yöresel lezzetlere ve geleneksel mutfak araçları gibi gastronomi unsurlarına yer verilmediği, görsel paylaşımlarının da az olduğu dikkat çekmiştir. Tüm bu bilgiler doğrultusunda paydaşların web sitelerinde yer alan gastronomi bilgi içerikleri; Kocaeli mutfağı ve özellikleri, Yöresel yemekler, Yöresel yemek tarifleri, Yöresel yiyeceklerin görselleri, Yöresel tarım ürünleri, Yöresel tarım ürünlerinin görselleri, Restoranlar ve tanıtım bilgileri, Yiyecek çeşitliliği, Kültürel Kimlikler/çeşitlilik, Gastronomi Festivalleri vb. etkinlikler başlıklarında öne çıkmıştır. Bu başlıklar aslında Kocaeli'nin gastronomik kimliğinin de bir göstergesidir. Harrington (2005) tarafından tanımlanan "gastronomik kimlik" kavramı, bir bölgenin yeme içme ile ilişkili özelliklerinin çevre ve kültür olmak üzere iki temel faktör tarafından oluşturulduğunu vurgulamaktadır. Gastronomik kimliği oluşturan çevre faktörü 
altında coğrafya, iklim, mikro iklimler, yöreye ait ürünler ve yeni ürünlerin yöreye uyumu yer alırken; kültür faktörü altında tarih, etnik çeşitlilik, deneme yanılma, gelenekler, inançlar ve değerler yer almaktadır. Destinasyonun sahip olduğu çevresel ve kültürel faktörler de destinasyon mutfağının kendine özgü özelliklerinin, diğer bir deyişle gastronomik kimliğin şekillenmesinde etkili olmaktadır. Gastronomik kimliğin çıktıları da destinasyonun çevresel ve kültürel özelliklerini taşıyan yerel yiyecek -içecekler ile yerel yemekler olmaktadır (Nebioğlu, 2017: 41). Bu kapsamda Kocaeli'nin kültürel faktörlerinin belirlenmesinde etkili olan demografik yapısına bakıldığında; Çerkezler, Gürcüler, Abhazlar gibi Kafkas halklarından, Boşnaklar, Bulgaristan, Arnavutluk, Yunanistan, Makedonya vb. Balkan halklarına ve hatta ülkemizin Karadeniz, Doğu Anadolu halklarından, Kocaeli ili yerlisi sayılan Manavlara kadar zengin bir çeşitlilik gösterdiği vurgulanmaktadır. Kocaeli'nin bu kültürel kimliklerle özdeş yemeklerinin gastronomi ürünlerine yansıyarak çok çeşitli ve zengin bir mutfak kültürünü içinde barındırdığ ifade edilmektedir (Üzümcü vd., 2017:133). İlaveten Kocaeli'nin çevre faktörlerine bakıldığında; eşsiz doğası (göl-dağ- deniz üçlüsü) ve zengin flora/ faunası, yörede yetişen sebze/ meyve ve hayvansal gıdalarda da çeşitlilik yaratmaktadır. Bu kapsamda Kocaeli mutfağının genellikle yöresel otlar olmak üzere hamur işi yiyeceklerden oluştuğu, daha az olarak et yemeklerinin sofralarda yer bulduğu söylenebilir. Kısacası web sitelerinde yer alan gastronomi bilgi içerikleri Kocaeli'nin gastronomik kimliğinin şekillenmesine ve ortaya çıkarılmasına yönelik önemli bilgiler sunmaktadir.

Bulgular kapsamında görülmüştür ki; destinasyon yönetimi paydaşlarından bazıları "Turizm Rehberi" hazırlayarak web sitelerinde paylaşmıştır. Bu kapsamda Kocaeli Büyükşehir Belediyesi'nin web sitesi ana sayfasında "Kocaeli ve Turizm" başlı̆̆ altında "Kocaeli Turizm Rehberi" ne yer verilmiştir. Turizm rehberinde yerel gastronomi ürünleri Türkçe "Nerede Ne Yenilir Ne Alınır?" ve İngilizce "What To Eat? What To Buy?" başlıkları altında yer almıştır. Rehber 220 sayfadan oluşmuş, 17 sayfası (151-168. sayfalar) yerel gastronomi ürünlerine ayrılmıştır. İzmit Belediyesi web sitesi ana sayfasında da "Turizm" başlığı altında "Turizmit" adıyla bir turizm rehberi vardır. Rehber 35 sayfadan oluşmuş, sadece 1,5 sayfasında gastronomi ürünlerine yer verilmiştir. Kartepe Belediyesi web sitesi ana sayfasında ise "Turizm" başlığ altında "Kartepe'de Turizm Rehberi" oluşturulmuştur. Dört bölümden oluşan bu başlığın bir bölümünde "Nerede Yemek Yenir" alt başlı̆̆ yerel gastronomi ürünlerine ayrılmıştır. Kartepe turizm rehberinin geneline bakıldığında gastronomi ürünlerinin diğer üç bölüm kadar yer aldığı görülmüştür. Bu bulgu önemli bir turizm destinasyonu olan Kartepe'ye gelen ziyaretçilerin yeme içme ihtiyaçlarına yönelik bilgilendirildiğini ancak yukarıda da ifade edildiği gibi sadece ticari restoranlar kapsamında bilgilendirmenin yapıldığını yerel gastronomi çekiciliklerinden yeterince yararlanılmadığını göstermiştir. Genel olarak destinasyon paydaşlarının çoğunun yerel gastronomi çekiciliklerine yer vermediği, turizm rehberi oluşturmadığı, oluşturan paydaşların da Kocaeli'yi temsilen turizm rehberlerinde yerel gastronomi ürünlerine yetersiz düzeyde yer verdiği görüldügünden paydaşların destinasyon rekabetini gastronomi unsurları üzerine kurmadığı anlaşılmıştır. Bu bulgu, Yılmaz ve Özdemir'in (2015) benzer çalışmasında belirttiği gibi, Hjalager'in (2002) tanımladığı destinasyonların gastronomi turizmindeki gelişim safhalarından ilki olan mevcut yerel gastronomik ürünlerin daha fazla turist çekmek için kullanılması safhasında kaldığı sonucuyla paralellik göstermiştir.

\section{Tema 3: Web Sitelerinde Gastronomi Bilgi İçeriklerine Ulaşılabilirlik}

Destinasyon yönetimi paydaşlarının web sitelerinde yerel gastronomi bilgi içeriklerine ulaşılabilirlik değerlendirilmiştir. Bu kapsamda: Kocaeli İl Kültür ve Turizm Müdürlüğü ‘Kültür' 'Yöresel Yemekler', Başiskele Belediyesi 'Başiskele'yi Keşfet' 'Nerede Yemek Yenir', Gebze 
Belediyesi 'Tarihçe' 'Yöresel', Dilovası Belediyesi 'Dilovası'nı Tanıyalım' 'Kültür ve Turizm', Gölcük Belediyesi 'Turizm' 'Yemek Kültürü', İzmit Belediyesi 'Turizm' 'Turizmit', Kartepe Belediyesi 'Turizm' 'Kartepe'yi Tanıyalım', Kocaeli Büyükşehir Belediyesi 'Kocaeli ve Turizm' 'Turizm Rehberi' alt başlıklarından yerel gastronomi ürünlerine dolaylı olarak ulaşılmıştır. Sadece Kocaeli Valiliği'nin web sitesinde doğrudan yerel gastronomi ürünlerine yer verilmiştir. Çoğunlukla web sitelerinde birkaç alt başlıktan sonra bilgilere ulaşıldığı bu durumda yöreyi ziyaret etmek isteyen turistlerin yerel gastronomi unsurları hakkında güvenilir bilgilere hızlı ve kolay ulaşamadıkları anlaşılmıştır. Bu durum, turisti seyahatini planlama aşamasında iken destinasyondan uzaklaştırdığını ve Kocaeli'nin destinasyon rekabetini daha web sitesinde kaybedebileceğini ortaya koymuştur. Destinasyona ait web sitelerinin, destinasyon tanitımındaki önemi ve ziyaretçilerin en kolay ulaşabileceği bilgi kaynağı olması nedeniyle paydaşların turistleri destinasyona güdülemeye yönelik web sitelerini yeniden düzenlemeleri önem arz etmektedir.

Destinasyon tanıtımı ve pazarlamasında önemli bir araç olan sosyal medyanın, seçilen merkezi ve yerel yönetimlerin tümü tarafından kullanıldığı ve web sitelerinden sosyal medya hesaplarına erişimin sağlandığı anlaşılmıştır. Sosyal medya gastronomi ürünlerinin tanıtılmasında, yayılmasında etkilidir çünkü bu hesaplar ağızdan ağıza pazarlama aracı olarak görev yapmakta ve turizm rekabet gücü için stratejik bir önem sağlamaktadır. Bu anlamda yerel yönetimlerin bu gücü kullandığı görülmüştür. Gölcük Belediyesi'nin web sitesinde site içi arama özelliğinin olması da ziyaretçilerine navigasyon hizmeti sunduğunu ve site içinde kaybolmalarını engellediğini ya da istedikleri bilgilere çabuk ulaşmalarını sağlamaya yönelik hizmet sunduklarını göstermiştir. Özetle seçilen merkezi ve yerel yönetimlerin günümüzde önemli bir destinasyon pazarlama aracı olan sosyal medyayı kullandıkları ancak gastronomik çekicilikler üzerinden kullanım amaçlarını öncelemedikleri anlaşılmıştır. Sosyal medya turizm aktivitesinde bulunmak isteyenlerin en kolay ulaşabilecekleri bir mecra olarak yüksek etkileşimli yapısından dolayı yönlendirici ve destekleyici bir role sahiptir. Bu kapsamda bilgi teknolojisinin huzla gelişmesiyle birlikte, pazarlama araçları ve stratejileri için müşteri-müşteri etkileşiminin emsalsiz önemini ortaya koymaktadır (Aktan, 2018: 232).

Elde edilen veriler çerçevesinde bazı paydaşların web sitelerinde çoklu dil seçeneğinin olması gastronomi bilgilerine ulaşmayı kolaylaştırmaktadır. Ancak bu sayı sınırlı ve yetersizdir. Kartepe Belediyesi'nin web sitesinde Türkçe haricinde iki dil (İngilizce, Arapça), Kocaeli İl Kültür ve Turizm Müdürlüğü ile merkez ilçe olan İzmit Belediyesi'nin web sitesinde ise bir dil (İngilizce) seçeneği olduğu görülmüştür. Ancak yönetimlerin çoğunda çoklu dil seçeneği olmadığı bu nedenle sadece yerli turistlere seslendikleri, yabancı turist kazanmaya yönelik gastronominin çekiciliğinden yararlanmadıkları bu kapsamda destinasyonu tanıtmaya ve gastronomi turizmini geliştirmeye yönelik web sitelerinde etkili bir pazarlama iletişimi izleyemedikleri anlaşılmıştır. Kirdkoh ve Ngamrung (2019), iki dille hazırlanan web sitelerini incelemiş ve satışı artırmak için iki dille hazırlanan web sitelerinin etkili bir pazarlama iletişim aracı olduğunu ortaya koymuştur. Eryılmaz ve Zengin'de (2011) destinasyon pazarlamasında web sitelerinin rolünü araştırmış, yabancı turistlere hitap edilebilmesi için web sitelerinin farklı dillerde hazırlanmış olması ve siteyi ziyaret edenlerin "dil seçeneği" menüsünden seçimlerini yapabilmeleri gerektiğine yönelik bir model önerisi sunmuşlardır. Bu nedenle paydaşların web sitelerinde çoklu dil seçeneğini kullanmaları önemli ve gereklidir. Çünkü destinasyon web siteleri, turistler için önemli referans kaynaklarıdır ve destinasyon imajı üzerinde olumlu etkilere sahiptir. Özellikle küresel ölçekte bölgelere ve turizm işletmelerine yönelik turistlerin dikkatini çekme ve talebi kendine yönlendirerek, rekabet avantajına sahip olmalarında web siteleri etkili olabilmektedir (Ünal ve Çelen, 2020: 31). 


\section{Tema 4: Web Sitelerinde Paylaşılan Gastronomi Bilgi İçeriklerinde Uyum}

Seçilen paydaşların web sitelerinde yer alan gastronomi bilgi içeriklerinin incelenmesi kapsamında destinasyon yönetimi paydaşlarının ortak bir yönetim anlayışı sergileyemedikleri bu kapsamda paydaşlar arasında koordinasyon eksikliği olduğu görülmüştür. Oysa seçilen merkezi ve yerel yönetimlerin özellikle destinasyon tanıtımı açısından aktif bir rol üstlenmelerinin, destinasyon yönetiminin etkinliği açısından önemli olduğu, bu paydaşların işbirliği ve uyum içerisinde hareket etmesinin etkiyi arttıracağ ifade edilmiştir (Akkuş ve Akkuş, 2019: 253). Çünkü paydaşlar arasında amaç birliği sağlanarak uzun süreli strateji geliştirilmesi sonucu ortaya çıkan koordinasyon, rekabetin artmasında ve hedeflere ulaşılmasında oldukça etkili olmaktadır. Bu kapsamda özellikle planların sürdürülebilirliğinin sağlanması, uzun dönemli maliyetlerin azalması ve arzu edilebilir politikaların oluşturulabilmesi için destinasyon yönetimi paydaşlarının uyum içinde çalışmaları önemlidir (İnanır, 2019: 527).

\section{SONUÇ ve ÖNERILER}

Kocaeli destinasyon yönetimi paydaşları arasından seçilen Kocaeli Valiliği, İl Kültür ve Turizm Müdürlüğü ile il ve ilçe belediyelerin web sitelerinde yaptığı gastronomi unsurlarına yönelik bilgilendirmelerin içeriğini ortaya çıarmak ve destinasyon pazarlaması ve rekabetçiliğinde gastronomi ürünlerinin kullanımını değerlendirmek amacıyla yapılan bu çalışmada aşağıdaki sonuçlara ulaşılmıştır.

Seçilen destinasyon yönetimi paydaşlarının web sitelerinde yer alan gastronomi bilgi içeriklerinde; Kocaeli mutfağı ve özellikleri, yöresel yemekler- reçeteleri ve görselleri, yöresel tarım ürünleri ve görselleri, gastronomi festivalleri, restoranlar, kültürel kimlikler ve yiyecek çeşitliliği başlıklarının öne çıktığı tespit edilmiştir. Bu kapsamda turizmin geliştirilmesi ve yönetilmesi konusunda etkin kurumlar olan Kocaeli Valiliği ile ìl Kültür ve Turizm Müdürlüğü'nün web sitelerinde yerel gastronomi ürünlerine (pişmaniye, sebze, et ve hamur işi yerel lezzetler) yönelik bilgilendirme yapıldığı saptanmıştır. Bu durumda paydaşların bölgesel rekabette avantaj elde etmeye çalıştıkları ve destinasyona özgü olma özelliğiyle fark yaratan bir pazarlama unsuru olarak yerel gastronominin çekiciliğinden kısmen yararlandıkları ortaya koyulmuştur. Bu durumun belediyeler açısından da benzer olduğu belirlenmiştir. Çalışma kapsamına alınan on üç belediye arasından yedi belediyenin web sitelerinde yerel gastronomi ürünlerine yeterli olmasa da yer verildiği ancak altı belediyenin web sitesinde gastronominin hiçbir unsuruna yer verilmediği tespit edilmiştir. Bazı belediyelerin ise yerel gastronomi ürünlerinin yerine restoranların mönülerinde yer alan yemekleri tanıtarak, işin ticari boyutunu öncelediği yerel yemeklerin sunulduğu yerel restoranların da destinasyonda pek bulunmadığ dikkat çekmiştir. Bu kapsamda web sitelerinde yer alan gastronomi bilgi içerikleri genellikle en çok bilinen pişmaniye, simit gibi yerel gastronomi ürünleriyle sınırlı kalmış, gastronomi turizmi kapsamında ele alınabilecek gastronomi pazarları, yiyecek üretim yerlerine seyahatler, gida fuarları, yemek şovları, yöresel ve kaliteli yiyecekleri deneyimlemeye yönelik aktiviteler konusunda bilgilendirme yapılmadığı ortaya koyulmuştur. Bu durumda gastronomi ürünlerinin destinasyon pazarlamasında etkili bir araç olarak kullanılmadığı, etkili iletişimin sağlanamadığ 1 dolayısıyla gastronomi potansiyeli yüksek olan Kocaeli'nin bu durumu rekabet avantajına çeviremediği saptanmıştır.

Paydaşların çoğunun web sitelerinde tarımsal ürünlere yer verildiği ancak Gölcük belediyesi dışında tarımsal ürünlere yönelik gastronomi festivallerine/ etkinliklerine yer verilmediği saptanmıştır. Bu kapsamda destinasyonun tanıtılmasında ve pazarlamasında festivallerin yüksek etkisinin kullanılamadığı, Kocaeli'nin ulusal ya da uluslararası çapta bilinirliğine yeterli 
katkı sağlanamadığı, gastronomi turizminin gelişimine ve destinasyonunun sürdürebilirliğine de yeterli destek verilemediği gibi yerel kalkınmanın gelişmesine de katkı sunulamadı $\breve{g} /$ sunulamayacağı ortaya koyulmuştur. Bu kapsamda destinasyon tanıtımı ve rekabeti konusunda gastronomik bilgilendirmenin yeterli ve etkin yapılmadığ 1 ve destinasyon pazarlamasının bu yönüyle eksik bırakıldığı sonucuna ulaşılmıştır. Destinasyonların pazarlamasında gastronomik etkinliklerin önemi ve destinasyonu özel yapan bu etkinliklerle destinasyonunun popülaritesinin artacağı unutulmamalıdır.

Çoğu paydaşın web sitelerinde önemli bir turizm ürünü olan gastronomi bilgi içeriklerine doğrudan ulaşılamadığı dolayısıyla destinasyonu ziyaret etmeyi düşünen turistlere hızlı ve güvenilir bilgi verilemediği tespit edilmiştir. Bu tespit; turistin seyahatini planlama aşamasında iken destinasyondan uzaklaşabileceğini ve Kocaeli'nin destinasyon rekabetini daha web sitesinde kaybedebileceğini ortaya koymuştur. Destinasyona ait web siteleri tanitım ve pazarlama aracı olarak ziyaretçilerin en kolay ulaşabileceği bilgi kaynağı olduğundan Kocaeli destinasyon paydaşlarının yerel gastronomi çekiciliğine yönelik ortak mesaj vermeleri ve web sitelerini güncellemeleri destinasyon yönetim etkinliğinin artırılmasında önemlidir.

Sonuç olarak, paydaşlara ait web sitelerinde gastronomi unsurlarına yeterince yer verilmediği, web sitelerinin birinde yer alan bilgilerin diğerinde olmadığ1 (koordinasyon eksikliği), güncel bilgilerin paylaşılmadığı ve yerel gastronominin çekiciliğinden yeterince yararlanılmadığı tespit edilmiştir. Bu tespit ile Kocaeli'nin zengin gastronomi potansiyeline rağmen destinasyon rekabetinin gastronomi ya da gastronomi turizmi üzerine kurulmadığı ortaya koyulmuştur. Bu durumda gastronominin/gastronomi turizminin destinasyon pazarlama aracı olarak etkili kullanılmadığı, Kocaeli'nin turizm gelirlerini artırmak, istihdam yaratmak, gastronomi turizminin etkisiyle turizmi bölgesel ve mevsimsel olarak (on iki aya) yaymak, turistlerin ilgisini sürdürmek, kısacası Kocaeli'de sürdürebilir turizmi sağlamak amacıyla gastronominin çekiciliğine yönelik ortak bir yönetim anlayışı benimsenmediği sonucuna ulaşılmıştır.

Bu sonuçlar doğrultusunda aşağıdaki öneriler getirilmiştir.

* Kocaeli destinasyon yönetimi paydaşları, destinasyonun sürdürebilirliği ve yerel kalkınmanın sağlanabilmesi için ortak bir destinasyon yönetim planı hazırlamalıdır. Gastronomi ürünlerinin sürdürülebilirliği yerel halkın kalkınmasına da katkı sağlayacağından bu planda gastronomi çekiciliklerine turizm değeri olarak özel bir yer verilmelidir.

* Destinasyon yönetimi paydaşları bir araya gelerek gastronomi çekiciliklerine yönelik hazırlanan plan çerçevesinde web sitelerini düzenlemeli ve koordineli çalışarak bu konuda ortak mesaj vermelidir.

* Tüm paydaşlar Kocaeli'nin gastronomik çekiciliğini destinasyon tanıtımı ve pazarlamasında rekabet avantajı sağlayacak şekilde kullanmalıdır. Bu kapsamda Yaratııı Şehirler Ağı'na Gastronomi Şehri olarak katılabilecek potansiyele sahip olan Kocaeli'nin, bu potansiyeli web sayfalarında görünür olmalıdır. Kocaeli destinasyon yönetimi paydaşlarının Yaratıcı Şehirler Ağı'na Gastronomi temasıyla üye olabilmek için başvuru yapması ve sürecin web sitelerinden güncellenerek duyurulması destinasyonun imajı, sürdürülebilirliği ve kalkınması bakımından önemlidir.

* Gastronomi turizminin geliştirilmesi ile turizm faaliyetleri tüm yıla yayılabilir, böylece Kocaeli tüm yıl boyunca turizm etkinliklerine ev sahipliği yapabilir ve turistik cazibe merkezi haline gelebilir.

* Kocaeli gastronomi potansiyeli göz önüne alınarak web sitelerinde daha fazla gastronomi çekiciliklerine (yemek reçeteleri, yemeklerin yapılışı ve hikayeleri, festivaller, geleneksel araçlar vb.) yönelik bilgilendirmeler yapılmalı ve bu bilgilendirmeler güncellenerek farklı dillerde hızlı 
ve güvenilir bir şekilde web sitesi ziyaretçilerine ulaştırılmalıdır. Gastronomi bilgi içerikleri yazılı ve/veya görsel metinler olarak (video, resim, yazı gibi) farklı formatlarda hazırlanmalı ve ziyaretçilerin dikkati çekilmelidir. Böylece destinasyona ulusal ve uluslararası düzeyde turist çekilebilir, tanınırlı̆̆ artabilir, yerel kalkınmaya ve çarpan etkisiyle ülke kalkınmasına katkı sağlanabilir.

* Coğrafi işaretli ürünlerin başvuru süreçleri takip edilerek tamamlanmalı, bu ürünlere yerel restoranlarda yer verilerek turizme kazandırılmalı ve web sitelerinden mutlaka duyurulmalıdır.

* Kocaeli'nin zengin gastronomi potansiyelini tanitacak ve turistleri destinasyona güdüleyecek yaşayan gastronomi müzeleri açılmalı ve bu müzeler web sitelerinde sanal tur kapsamında ziyaretçilere gezdirilmelidir. Böylece gastronomi turizmi kapsamında destinasyon pazarlaması ve rekabetinde avantaj sağlanmalıdır.

Bu çalışmada gastronomi ürünlerinin destinasyon pazarlaması ve rekabetindeki önemine vurgu yapılarak destinasyon yönetimi paydaşlarının konuya dikkatini çekmek istenmiştir. Literatürde Kocaeli özelinde benzer bir çalışmaya rastlanılmaması çalışmayı bu yönüyle önemli kılmakta ve Kocaeli destinasyon pazarlaması ile gastronomi alan yazınına katkı sağlaması ümit edilmektedir.

\section{KAYNAKLAR}

Akkuş, G. ve Akkuş, Ç. (2019). Merkezi ve Yerel Yönetimlerin Resmi Web Sitelerinde Yer Alan Bölgesel Turizm Değerlerine İlişkin Bilgilerin Karşılaştırılması, V Uluslararası Türk Dünyası Turizm Sempozyumu / 13-15 Haziran, Taraz - Kazakistan, Bildiriler Kitabı, s.252-267.

Aktan, E. (2018). Sosyal Medyanın Turizm Pazarlamasındaki Rolünün Değerlendirilmesi, Journal of Tourism and Gastronomy Studies, 6 (3): 228-248.

Albayrak, S. (2013). Alternatif Turizm, Ankara: Detay Yayıncilık.

Alyakut, Ö. (2017). Gastronomi Turizmi, (Editör) Karacan, S.: Turizm Okumaları I içinde (ss. 111), Kocaeli: Umuttepe Yayınları.

Alyakut, Ö. ve Küçükkömürler, S. (2019). Kocaeli Gastronomi Potansiyelinin Yaratıcı Şehirler Ağ1 Kapsamında Değerlendirilmesi, Uluslararası Orhan Gazi ve Kocaeli Tarihi- Kültürü Sempozyumu V, Kocaeli, Bildiriler Kitabı.

Alyakut, Ö. ve Üzümcü Polat, T. (2017). Gastronomi Turizmi Açısından Kandıra Beslenme Kültürü ve Unutulmuş Lezzetleri, Çoban Mustafa Paşa ve Kocaeli Tarihi-Kültürel Sempozyumu IV, Kocaeli, Bildiriler Kitabı.

Aydoğdu, A., Okay Özkaya, E. ve Köse, C. Z. (2016). Destinasyon Tercihinde Gastronomi Turizminin Önemi: Bozcaada Örneği, Uluslararası Türk Dünyası Turizm Araştırmaları Dergisi, 1(2): 120-132.

Aydoğdu, A. ve Duman, S. (2017). Destinasyon Çekicilik Unsuru Olarak Gastronomi Turizmi: Kastamonu Örneği, Turizm ve Araştırma Dergisi, 6 (1): 4-23.

Benli, S. ve Güler, O. (2019). Web Sitelerinin Gastronomi Çekim Unsurları Kapsaminda İncelenmesi: Gaziantep, Hatay ve Adana İl Kültür ve Turizm Müdürlügü Web Sitelerinin Analizi, 3. Uluslararası Turizmin Geleceği Kongresi: İnovasyon, Girişimcilik ve Sürdürebilirlik Kongresi, Proceeding Book, 55 (3): 828-833.

Bulut, H. S. (2019). Ulusal Gastronomi Kimliğinin Geliştirilmesi Ve Turistik Tanıtımında Karşılaşılan Sorunlar, Inönü University Journal of Culture and Art, 5 (1): 60-65. 
Çakır, F. ve Küçükkambak, S. E. (2016). Destinasyon Pazarlaması Ve Fethiye Yöresinin Algılanan İmajının Ölçümü Üzerine Ampirik Bir Araştırma, Gazi Üniversitesi İktisadi ve İdari Bilimler Fakültesi Dergisi, 18/2: 400-425.

Çalışkan, O. (2013). Destinasyon Rekabetçiliği ve Seyahat Motivasyonu Bakımından Gastronomik Kimlik, Journal of Tourism and Gastronomy Studies, 1 (2): 39-51.

Çevik, S. ve Saçıllk, M. (2011). Destinasyonun Rekabet Avantajı Elde Etmesinde Gastronomi Turizminin Rolü: Erdek Örneği, 12. Ulusal Turizm Kongresi 30 Kasım - 4 Aralık 2011, Akçakoca

Çiçek, E. ve Pala, U. (2017). Destinasyon Markalaşması Üzerine Bir Araştırma: Tarsus Örneği, Çă̆g Üniversitesi Sosyal Bilimler Dergisi, 14 (2): 25-47

Çiçek, E., Pala, U. ve Özcan, S. (2013). Destinasyon Tercihinde Web Sitelerinin Önemi: Yerli Turistler Üzerine Bir Araştırma, Sosyoteknik Sosyal ve Teknik Araştırmalar Dergisi, 3 (5): 1-14.

Deniz, T. ve Atışman, E. (2017). Kayseri İlinin Gastronomi Turizmine Yönelik Bir SWOT Analizi Çalışması, Türk Turizm Araştırmaları Dergisi, 1 (3): 56- 65.

Doğaner, M. C. ve Armağan, E. (2017). Seyahat Bloglarının Destinasyon Seçimine Etkisi, Pamukkale Üniversitesi Sosyal Bilimler Enstitüsü Dergisi, 30: 223-237.

Draskovic, S. (2016). Gastronomy and Tourism Destination Competitiveness, Singidunum International Tourism Conference-Sitcon, Belgrad/Surbistan, s.150-154

Duğan, Ö. ve Aydın, O. B. (2018). Sosyal Medyanın Turizmde Tanıtım Amaçlı Kullanımı: T.C. Kültür ve Turizm Bakanlı̆̆ı Örneği, Uluslararası Türk Dünyası Turizm Araş. Dergisi, 3 (1): 1-13.

Elden, M. (2003). Reklam Yazarlı̆̆ı, İstanbul: İletişim Yayınları.

Eryılmaz, B. ve Zengin, B. (2011). Destinasyon Pazarlamasında Web Sitelerinin Rolü ve Önemi, X. Geleneksel Turizm Paneli.

Genç, K., Atay, L. ve Eryaman, M.Y. (2014). Sürdürülebilir Destinasyon Yaratma Sürecinde Örgütlenmenin Önemi: Çanakkale Turizmi Üzerine Bir Araştırma, Anatolia: Turizm Araştırmaları Dergisi, 25 (1): 49 - 61.

Getz, D. (2008). The Nature and Scope of festival Studies, International Journal of Event Management Research, 5 (1): 1-47.

Göker, G. (2011). Destinasyon Çekicilik Unsuru Olarak Gastronomi Turizmi (Balıkesir Örneği), Yayınlanmamış Yüksek Lisans Tezi, Balıkesir Üniversitesi, Balıkesir.

Güçer, E., Hassan, A. ve Pelit, E. (2013). Destinasyon Pazarlamasında Belediye Web Sayfalarının Önemi: Türkiye' deki Büyükşehir Belediyelerinde Bir İnceleme, Manas Sosyal Araştırmalar Dergisi, 2 (8): 47-62.

Güllü, K. (2018). Destinasyon Tanıtımında Yerel Yönetimlerin Rolü: Belediyelerin Web Siteleri Üzerine Bir Araştırma, Reforma, 3: 38-51.

Gülen, M. (2017). Gastronomi Turizm Potansiyeli ve Geliştirilmesi Kapsamında Afyonkarahisar İlinin Değerlendirilmesi, Güncel Turizm Araştırmaları Dergisi, 1 (1): 31-42.

Hacıŏlu, N. (2010). Turizm Pazarlaması, Ankara: Nobel Yayıncilık.

İlban, O. M. ve Kömür, T. (2019). Destinasyon Markalaşmasında Festival Turizminin Rolü: Ayvalık Uluslararası Zeytin Hasat Günleri Örneği, Journal of Travel and Hospitality Management, 16 (2): 274-295. 
İnanır, A. (2019). Turistik Destinasyon Yönetiminde Paydaşlar Arası İlişkiler: Göller Yöresi Örneği, Türk Turizm Araştırmaları Dergisi, 3 (3): 517-541.

İpar, M. S. (2011). Turizmde Destinasyon Markalaşması ve İstanbul Üzerine Bir Uygulama, Yayınlanmamış Yüksek Lisans Tezi, Balıkesir Üniversitesi, Balıkesir.

Karabıyık, N. ve İnci Sümer, B. (2012). Destinasyon Pazarlamasında Pazarlama Stratejisi ve Konumlandırma Çalışmalarına Kavramsal Yaklaşım, İstanbul Journal of Social Sciences, 1:1-19.

Karasar, N. (2011). Bilimsel Araştırma Yöntemi, Ankara: Nobel Yayınevi.

Kirdkoh, S. and Ngamrung, S. (2019). A Study of Bilingual Websites as a Marketing Communication Tool in Tourism Industry: The Case Study of Cafes in Phitsanulok, Thailand, Global Goals, Local Actions: Looking Back and Moving Forward, 1 (10): 97-102.

Kocaeli İl Kültür ve Turizm Müdürlüğü (2018). Yöresel Yemekler, https://kocaeli.ktb.gov.tr/TR69203/yoresel-yemekler.html, Erişim Tarihi: 06.12.2019.

Koç, H. İ. (2015). Üniversitelerde Web Sitelerinin Kurumsal İletişim Amaçlı Kullanımı: Devlet ve Vakıf Üniversitelerinin Web Siteleri Üzerine Karşılaştırmalı Bir Analiz, Gümüşhane Üniversitesi İletişim Fakültesi Elektronik Dergisi, 3 (2): 57-83.

Marangoz, M., Yeşildağ, B. ve Saltık Arıkan, I. (2012). E-Ticaret İşletmelerinin Web Ve Sosyal A $\breve{g}$ Sitelerinin İçerik Analizi Yöntemiyle İncelenmesi, Journal of Internet Applications \& ManagementIUYD, 3(2): 53-78.

Nebioğlu, O. (2017). Gastronomik Kimlik ve Gastronomik Turizm Ürünlerinin Sınıflandırılması Üzerine Nitel Bir Araştırma: Alanya Örneği, JOTAGS, 5 (2): 39-60.

Özdemir, G. (2007). Destinasyon Pazarlamasında İnternetin Rolü, Journal of Yasar University, 2 (8): 889-898.

Özdemir, G. (2014). Destinasyon Pazarlama Kavramı, Ankara: Detay Yayıncllı.

Rinaldi, C. (2017). Food and Gastronomy for Sustainable Place Development: A Multidisciplinary Analysis of Different Theoretical Approaches, Sustainability, 9 (1748): 1-25.

Sarl, Y. ve Kozak, M. (2005). Turizm Pazarlamasına İnternetin Etkisi: Destinasyon Web Siteleri İçin Bir Model Önerisi, Akdeniz İ.I.B.F. Dergisi (9): 248-271.

Sayımer, İ. (2012). Sanal Ortamda Halkla İlişkiler, İstanbul: Beta Yayınları.

Serçek, S. ve Serçek Özaltaş, G. (2015). Serbest Zaman Etkinlikleri Olarak Üniversite Öğrencilerinin Rekreatif Etkinliklere Katılmaları ve Sosyalleşmeleri Arasındaki İlişki, Akademik Bakış Uluslararası Hakemli Sosyal Bilimler Dergisi, 51: 1-21.

Şahin Güzel, G. ve Ünver, G. (2015). Destinasyon Pazarlama Aracı Olarak Gastronomi Turizmi: İstanbul'un Gastronomi Turizmi Potansiyeli Üzerine Bir Araştırma, JOTAGS, 3/2: 63-73.

Şen, A. ve Aktaş, N. (2017). Tüketicilerin Seyahatleri Sırasında Besin Seçimleri, Yöresel Gastronomi Davranışları ve Destinasyon Seçiminde Gastronomi Unsurlarının Rolü: KonyaKaraman Örneği, KMÜ Sosyal ve Ekonomik Araşttrmalar Dergisi, 19 (32): 65-72.

Toprakkaya, K. (2017). Türkiye'nin Gastronomi Turizmi Raporu açıklandı, Tourism Magazine (TOURMAG), 7 Aralık 2017 tarihli yazı, https://www.tourmag.com.tr/turkiyenin-gastronomiturizmi-raporu-aciklandi/, Erişim Tarihi: 02.12.2019.

Türkay, O. (2014). Destinasyon Yönetimi: Yönetimbilim Bakış Açısıyla İşlevler, Yaklaşımlar ve Araçlar, Ankara: Detay Yayıncllık. 
TDK (Türk Dil Kurumu), Destinasyon Kavramı, https://sozluk.gov.tr/, Erişim Tarihi: 01.12.2019.

Türkiye Seyahat Acentaları Birliği (TÜRSAB) (2014). Türkiye Gastronomi Turizmi Raporu, https://www.tursab.org.tr/tursab-gastronomi-turizmi-raporu_12302_3531549.pdf, Erişim Tarihi: 08.12.2019.

Uluçay, M. D. (2017). Gastronomi Turizmi İşletmelerinin Web Siteleri Üzerine Karşılaştırmalı Bir Değerlendirme, Erciyes İletişim Dergisi Akademia, 5 (2): 196-208.

Ünal, A ve Çelen, O. (2020). Destinasyon Pazarlama Araçlarından Web Sitelerinin Değerlendirilmesine Yönelik Nitel Bir Araştırma: Akdeniz Destinasyonları Örneği, Süleyman Demirel Üniversitesi Vizyoner Dergisi, 11 (26): 30-44.

Üzümcü Polat, T., Alyakut, Ö. ve Akpulat, A. N. (2017). Coğrafi İşaretleme Kapsamında Kocaeli Gastronomik Ürünlerinin Değerlendirilmesi, KMÜ Sosyal ve Ekonomik Araştırmalar Dergisi, 19 (28): 132-140.

Yamen, E. Kocaeli İl Kültür ve Turizm Müdürü, Başiskele Gel Gör Gez Projesi Açllış Konuşması, 25 Aralık 2019, Başiskele Kocaeli.

Yazıc1, T. ve Ekinci, K. (2017). Yavaş Şehirlerin Kurumsal Web Sitesi Kullanımı Üzerine Bir İnceleme: Cittaslow Türkiye Belediyeleri Web Sitesi Ana Sayfalarının Karşılaştırılması, 1st International Conference on New Trends in Communication, 4-7 May1s, İstanbul.

Yeşilyurt, E. (2019). Coğrafi İşaretli Ürünler https://www.kocaeli.bel.tr/tr/main/news/kultur/15/kocaeline-ozgu-10-urune-cografi-isaretalinac/33360, Erişim Tarihi: 12.12.2019.

Yıldırım, A. ve Şimşek, H. (2018). Sosyal Bilimlerde Nitel Araştırma Yöntemleri, Ankara: Seçkin Yayincilik.

Yılmaz, G. ve Özdemir, B. (2015). Yerel Gastronominin Tanıtım Materyallerindeki Yeri: Kapadokya Bölgesi Üzerine Bir Araştırma, I. Eurasia International Tourism Congress: Current Issues, Trends, And Indicators, 28-30 Mayıs, Konya, ss.760-780.

YUCiTA- Yöresel Ürünler ve Coğrafi İşaretler Türkiye Araştırma Ağı- (2013). Hukuki Boyut, http://yucita.org/Hukuki-boyut, Erişim Tarihi: 05.12.2019.

Zağralı, E. ve Akbaba, A. (2015). Turistlerin Destinasyon Seçiminde Yöresel Yemeklerin Rolü: İzmir Yarımadası'nı Ziyaret Eden Turistlerin Görüşleri Üzerine Bir Araştırma, Journal of Yasar University, 10 (40): 6633-6644. 